Volume 8, No.1.5, 2019

International Journal of Advanced Trends in Computer Science and Engineering

Available Online at http://www.warse.org/IJATCSE/static/pdf/file/ijatcse3781.52019.pdf

https://doi.org/10.30534/ịatcse/2019/3781.52019

\title{
Accounting Information System on Payroll Using Software (Case Study in Cooperative Companies Telecommunication of Molecular Balinusra Region)
}

\author{
Ni Nyoman Sudiyani, Ade Maharini Adiandari ${ }^{2}$, Luh Putu Virra Indah Perdanawati ${ }^{3}$, Ni Putu Yuliana Ria \\ Sawitri $^{4}$ \\ ${ }^{1}$ Ngurah Rai University, Indonesia, nyoman.sudiyani@unr.ac.id \\ ${ }^{2}$ Ngurah Rai University, Indonesia, maharini.adiandari@unr.ac.id \\ ${ }^{3}$ Ngurah Rai University, Indonesia, virra.indah@unr.ac.id \\ ${ }^{4}$ Ngurah Rai University, Indonesia, yulianariasawitri@yahoo.com
}

\begin{abstract}
The presence of an organization is emphatically impacted by the framework that keeps running inside the organization. A decent framework is a significant prerequisite for an organization. A decent framework is absolutely ready to help all exercises did by the organization in building up its business. One framework that is possessed by the organization as a rule is the bookkeeping framework. This bookkeeping framework is intended to introduce all data identifying with organization exercises. Data that is in all respects firmly identified with bookkeeping frameworks in organizations is money related data that is possessed by the organization. This data is required by different gatherings, both inward gatherings and outside gatherings. This investigation talks about bookkeeping data frameworks for Cellular or Kisel Telecommunications Cooperatives. In light of the aftereffects of research and dialog of the finance bookkeeping data framework at the Cellular Telecommunications Cooperative (Kisel) in Balinusra Region, it tends to be presumed that the bookkeeping data framework in the finance procedure has gone well since it is as per the hypothesis. The utilization of modernized frameworks significantly improves the errand of each part identified with finance in gathering, putting away, and preparing information. PCs associated online are extremely valuable for the data needs required on the grounds that they can get to information and data progressively.
\end{abstract}

Key words: Accounting Information Systems, Payroll, Software

\section{INTRODUCTION}

Normally, any Accounting Information System, (broadly known as) AIS, is formed of three noteworthy sub-frameworks: (1) Transaction Processing System (TPS) that supports every day and routine business procedures and tasks; (2) General Ledger and Factory Record framework and
Financial Reporting System (GL/FRS) and (3) Management Revealing Systems (MRS) [1]. Any AIS is a machine based system for following the bookkeeping and evaluating movement bolstered by data innovation and the pertinent assets [2]. Pretty much every sort of basic leadership including budgetary and non-money related which has any sort of effect on handling of business exchanges is constantly founded on AIS instruments for accumulation, investigation, stockpiling and controls of bookkeeping information (which works all the more proficiently and viably). Once more, TPS is the establishment stone of day by day tasks and procedures. Three major exchange cycles called transformation cycle combined with income and consumption cycles. Here, the motivation behind this data framework is robotize and manage, record and break down the money related issues in bookkeeping space being the first to help these exercises [3]. To be sure, the advancement of first PC machine by Charles Babbage give a foundation to PC based bookkeeping, particularly with the IBM702, which was utilized in 1953 for bookkeeping. GLS/FRS being the two of a kind or being named as turn in glove are two firmly related components, with GLS spreads recording and outline while estimation, announcing and basic leadership being the capacity of FRS individually. The yield of them might be as government forms, budget reports, for all the individuals from the partners [4]. MRS, for the most part gives data and essential sources of info for employment request costing, process costing, cost, volume and benefit examination, $\mathrm{ABC}$ costing, fluctuation investigation, Budgeting (present moment and long haul), money streams, finance and material taking care of including interminable and intermittent issues, EOQ, inside departmental moves, reward and right issues, proportion examination at one side and planning of branch accounts (autonomous and outside branches), transfer accounts, contract accounts, joint endeavor accounts, banking exchanges alongside the bank compromise explanations, money books, are set up at the opposite side.

For practically all experts from the bookkeeping space, the principle thought regarding the data arrangement of an association and especially an AIS is grasped by the Enterprise 
Ni Nyoman Sudiyani et al., International Journal of Advanced Trends in Computer Science and Engineering, 8(1.5), 2019,199 - 205

Resource Planning (ERP), which includes all the fundamental capacities to help an association and is executed in practically all enormous associations [5] [6]. Current writing by [7] is moving endlessly from this set up view about AIS space, thinking about now as an increasingly secluded way to deal with an AIS where new innovations like Business Intelligence (BI) or on the other hand Balanced Scorecard (BSC) frameworks assume an undeniably significant job [3] [8]. The work displayed flooded from this thought there is an enormous arrangement of new innovations that can supplement or coordinate current AIS and its present accessible offices. While it seems obvious that the slow acceptance of Information and Communication Technologies (ICT) has been a factor in the stagnation of the appointment scheduling process, this scheduling process can be loosely coupled from other health-care features. This loose coupling can allow the scheduling aspect of the health care industry to grow while leaving the option open for tighter coupling once ICT catches [9].

Kisel (Telecommunication Cooperative) is the principle business of Kisel occupied with Sales and Distribution Channel specialist co-ops (Sales and conveyance), General Services (general administrations), and Telco Infatructure (broadcast communications foundation administrations). The advancement of the Adempiere framework in Kisel was as yet unfit to make monetary reports in detail with the goal that the projects showed were as yet numerous weaknesses, particularly subtleties in detail beginning from income to Gross Profit Margin (GPM)/Operational Expenditure (OPEX) and the proportion couldn't speaking to at long last there are manual contributions to accumulate budget summaries appropriately. While the improvement of Adempiere is presently advancing with the goal that the fiscal summaries showed are altogether spoken to beginning from income to Gross Profit Margin (GMP)/Operational Expenditure (OPEX) in detail per thing all legitimately spoke to the office in Kisel to be specific HRD and $\mathrm{S}$ and $\mathrm{C}$ all developments can be observed viewing HR just as in $\mathrm{S}$ and $\mathrm{C}$ stocks and deals developments, and one of the administration exercises completed by the Cellular Telecommunication Cooperative (Kisel) in the Balimusra Region is the arrangement of compensations to all workers. Given the significance of bookkeeping data frameworks for Cellular or Kisel Telecommunications Cooperatives, analysts are keen on leading examination that takes the title: "Bookkeeping Information Systems in the Payroll Process Case Study of Cellular Telecommunication Cooperatives (Kisel) in Balinusra Region".

In view of the foundation of the issue over, the detailing of the issue in this examination are: What is the bookkeeping data framework in the finance procedure at the Selular Telecommunication (KiSEL) Cooperative in the Balinusra Region. The reason for the examination is to discover the bookkeeping data framework in the finance procedure utilized by the Cell.

\section{LITERATURE REVIEW}

\subsection{Accounting Information System}

The board on Accounting History of the American Accounting Association depicts accounting history as the examination of progression in accounting thought, practices, and establishments in response to changes in nature and cultural needs. Accounting, as it is directly known, just began to work out as intended in the fourteenth century; nevertheless, old Egyptians developed a course of action of principal accounting as on schedule as 3200-3000 B.C. In Pharaonic Egypt, another social affiliation developed, making a necessity for some sort of accounting structure. In this social structure, "the money related unit (inborn association) depleted was not the individual but instead the town. The obligation level on the towns was not abstractly doled out by the ruler and clerics, rather charge examinations what's more, specialists (copyists) met with the town chief, who may hoard the town counc il, to orchestrate the obligation. Moreover with any duty appraisal unit, there was every now and again abundance, and by virtue of Pharaonic Egypt, the issue of observing "majestic favors" developed. To comprehend these issues, "the money related surplus assembled as charges was composed toward the minister who by then redistributed some fragment through the various degrees of the organization, the haven craftsmans, and the workers who drudged on the distinctive strict and water driven assignments [10].

Moreover, in perspective on the "multifaceted nature" of checking items accumulated as royal gifts and cost abundance, "the progression of a complex accounting structure that recorded the two evaluations and portions and kept renowned favors separate from obligations" occurred [9]. In spite of the way that the accounting system may have been amazing and explain of that day and age, it seems, by all accounts, to be straightforward concerning current accounting. Believe it or not, "for the most part accounting history masters agree that old metro foundations, for instance, Egypt made bookkeeping as a sort of 'stores accounting' which just gives a load of what property was open" [10]. The entire Egyptian accounting structure is abbreviated in the composition review of an assessment by [11], titled Information Systems and Bookkeeping Practices in Ghanaian Public Institutions. This examination gives, "in old Egypt in the pharaoh's central cash division copyists organized records of receipts and disseminations of silver, corn and other commodit ies.

One recorder recorded on papyrus the entirety brought to the conveyance focus and another copyist checked the debilitating holders on the housetop as it was filled the limit building. Audit was performed by a third recorder who took a gander at these records. As of late communicated, it was not until the fourteenth century that accounting as today is acknowledged begun to outline in European countries. The advancement in ocean trade of Italian urban networks, for instance, Florence what's more, Venice achieved a creating prerequisite for a progressively start to finish and fusing 
accounting structure and shows. Resource reports were obvious from around 1400 and the Medici family had accounting records of 'material created and sold. Believe it or not, an enormous segment of the accounting wording used in the calling (assets, commitment, capital, and advantage, to give a few models) today finds builds up in the Latin language. As a result of industrialization around the world, new legitimate structures worked out as expected as the owners separated from the components causing extensive changes in the accounting calling [11].

As the mechanical agitation brought an industry focused economy rather than the agrarian focused economy previously set up, some kind of administering standards must be set up to keep tremendous associations and organizations pleasant with the open's needs and the economy's needs. The bleeding edge accounting considering filled these necessities. Correspondingly as with everything on the planet today, the accounting calling has been influenced by the imaginative world. As communicated by [12] incredibly, advancement has routinely been used to simply robotize existing manual methods and procedures, as opposed to first repeating issues and reengineering structures in light of new developments and limits. Bookkeeping information systems have been made to assist clerks with the extended degree of the calling, acknowledged by enhancements for the planet's social and fiscal fronts. There are a couple of interesting sorts of systems available to associations huge and minimal undefined. A segment of these systems are industry based, while others are progressively regular for little or multi-business use; in any case, all "mechanized accounting structures overhaul handiness of various accounting workplaces by extending without a minute to save accoun ting information. By overhauling common sense of fiscal information, accountants can plan reports and assignments examination that gives the officials a precise viewpoint on current undertakings. The amount of money related reports has been improved via computerized structures. Pay explanations, bits of the general business reports and departmental advantage and adversity are at present progressively accessible with computerized systems. A previous discernment shows an electronic accounting structure has internal check and evening out measures to ensure trades and records are fittingly balanced before the monetary reports are finally orchestrated. It furthermore ensures that individual trades are properly recorded in journal areas [11]. Accounting information structures have changed the accounting scene by helping accountants give dynamically accurate information in a for all intents and purposes minute reason. At present, if a business person needs to pursue the evening out sheet of the business, the owner is basically a few snaps of the mouse and strokes on the comfort away from making a minute see his money related record, while going before an accounting information structure, the owner would need to delay for the information to be collected and the declarations be made.

\subsection{Payroll System}

Most can recall their first check. It was conveyed by a chief who had gotten it from somebody in the bookkeeping office where the finance work was housed. The check was in a little envelope alongside a compensation slip expressing the hours worked, the rate, charges paid, and the sum encased. Checks go back preceding $1000 \mathrm{AD}$ and are thought to have been first utilized by traders in the Eastern Mediterranean. Known as "saak," they were like cutting edge checks in that they were archives with composed guidance to the bank to make installment to the payee [12]. Today the way toward paying representatives has turned into an unquestionably progressively refined, be that as it may, substantially less tedious, process for entrepreneurs. We have innovation to thank for it. Those old dealers sought the mists for indications of course in their business dealings; the present bookkeeping, human asset, and money related chiefs are looking to an altogether different "cloud" for the conveyance of a more astute, powerful. increasingly responsive, and more affordable finance arrangement ([14].

Above all else the finance specialist organizations have now jumped upon the cloud-based temporary fad [15]. In spite of this accessibility of bookkeeping innovation there are as yet an astonishing number of organizations utilizing manual records and spreadsheets to run their finance [14]. This winds up muddled when you consider associations in the USA are bound by law by [16] to store this data for as long as 7 years. Finance information is exceedingly private but then in numerous cases this data is held unreliably in file organizers or on a personal computer. The determination of a confided in cloud finance supplier to move this information out of the workplace what's more, off a committed PC into a safe server farm is basic. All inclusive the finance commercial center is very focused. Organizations have a wide assortment of specialist co-ops to look over and a decent arrangement of assessment should be attempted in request to choose the administration that is the privilege for each firm [17].

Finance enactment is additionally limitlessly unpredictable and an organization may need to totally rebrand its answer go from programming, for example, QuickBooks to other increasingly solid furthermore, good programming, for example, Reckon Accounts [18]. Finance frameworks should be very perfect and adaptable to be of significant worth to business. A finance framework arrangement is just compelling on the off chance that it can cover the center usefulness required for the business [19]. Huge numbers of the more up to date progressively "light" contributions may not do this to the level wanted. It pays to do your examination on contributions, to guarantee the arrangement you are thinking about has every one of the highlights you need. Today one sees an adjustment in the manner organizations approach finance frameworks. Customarily organizations have moved toward finance and finance frameworks as an issue of bookkeeping practices and IRS consistence. As enactment around finance, occasions, and other expense commitments have turned out to be progressively unpredictable, organizations are searching for 
approaches to meet their commitments all the more adequately as well as rearrange finance the board [14].

Innovation has worked admirably of taking the frequently testing and everchanging guidelines and making them simpler for organizations to oversee. There is a pattern among organizations needing to make finance a completely coordinated part of their business the board [13]. This reflects how significant it is for organizations to comprehend the linkage between their staff costs and their activity. The association has a basic need staff expenses to the only remaining penny to allot staff expenses toemployments. In this way a framework that guarantees your bookkeeping and your finance work firmly together is essential [18]. Participation Process and Payroll System" has an unequivocal job in supervision and upkeep of documentation for worker accounts as far as their accessibility and participation in the association which is valuable setting up the finance. Be that as it may, the procedure has complex overhead which makes it essentially tedious. The different segments to be determined cautiously including government disability advantages of a representative alongside the standard parameters like on employment time, impetuses, progresses, etc. Accuracy in figuring these segments is legitimately corresponding to confide in structure among representatives [20].

This work has considered the timetable and turnout of representatives in a lodging industry by sectioning it to grouped divisions. Every office has a boss, or an administrator regulate the participation of the representatives in the relating division. Each and every other office may keep up their own adaptable timetable for which the chiefs should be confined distinctly to their relating divisions to stay away from clashes in organization. In any case, the General Manager may have the benefit to control the participation independent of offices to guarantee order and smooth work process. The whole report of participation is additionally examined by a bookkeeper to give it as contribution to the finance programming. A typical pattern in lodging industry is to offer additional stipends to wedded representatives whose mate isn't utilized with some association [21]. The office of additional remittance helps in sparing the assessment for the budgetary year.

\subsection{Software}

In an association, there are numerous divisions and each division has a finance segment to deal with its finance exercises. Each segment needs to perform essential activities like information gathering and arrangement, passage, updates, checking and detailing of information. A considerable lot of these existing practices and methods should be reassessed at this season of evolving needs, changing requests of representatives and changing innovations [22]. With this finance framework, finance segment would most likely keep a record of workers including their faculty information, pay slips, stipends, findings, leave, reserve funds and duties and so on. Net pay of every representative is determined by his stipends what's more, findings referenced by the organization rules. The individual pay slips are printed out as a receipt if worker needs to get a print out. Pay groups, grade pay, stipends, reasonings and duty data are refreshed if there is any alteration in pay structure. The PC based finance application is an electronic structure. The server-side of this application is apportioned as far as rationale into three-levels or layers.

Different Autonomous programming applications, ordinarily exhibited by the terms like administrations, web or e-administrations and web administrations are recognized through one of a kind code known as uniform asset identifier (URI), gotten to by institutionalized and tweaked conventions like HTTP, XML or SOAP [23]. Web is viewed as the grass root base for online correspondence as intranet or extranet. All the data stream which flows in the association in the start to finish or base to top, is bolstered by Undertaking Application Integration (EAI), which means co-appointment among customers and providers. Today, these administrations encourage AIS, web applications and operational frameworks, and this expand constant revealing and outside answering to every one of the gatherings having stake with the organization. The full time and genuine openness is a definitive result of the majority of this dialog in this paper. Decrease in liquidity hazard and decrease in the choice of antagonistic providers/merchants brings about expanded budgetary execution which helps the associations with respect to budgetary viewpoints [24]. Therefore computerization, speculators and leasers are presently all around educated partners which results in lower odds of misfortune and top notch monetary and bookkeeping information bank for future designs and execute the current plans in like manner. Online information is the pre imperative of on line exchanging and associations utilized their sites to show their information publically and it additionally satisfies the consistence prerequisite [4]. It likewise encourages in the best possible execution of guidelines and guidelines so as to maintain the administration necessities. There is likewise a blend of electronic and web empowered bookkeeping programming which is giving administrations to the administrators. Presently, web based charging and invoicing is fundamentally utilized by each kind of business association bolstered by Link Point, PayPal and Authorize.net. These give solid, substantial secure, quick doors of business exchanges. Presently, the new scope of administrations incorporate help system organize for key direction for key planning.

\section{RESEARCH METHODOLOGY}

To obtain the data needed in this study, researchers conducted a study on the telecommunication cellular cooperative (Kisel) of Balinusra Region located on Cokroaminito street no 99a Denpasar-Bali. The object of research is the accounting information system in the payroll process case study in the selular telecommunications cooperative (Kisel) in the balinusra region covering payroll systems, document flow charts, documents used, notes and reports relating to payroll. 
The analysis technique in this study uses descriptive qualitative analysis, namely by describing the state of the payroll system in the cellular telecommunications cooperative (Kisel) in the region of balinusra, comparing the existing theories and practices of the cellular telecommunication cooperative (Kisel) in Balinusra region, describing and identifying components of information systems payroll accounting used by the cellular telecommunication cooperative (Kisel) in Balinusra region with a theoretical accounting information system component which will be explained descriptively according to the indicators of accounting information system components.

\section{FINDINGS}

Payroll accounting system carried out by cellular telecommunication cooperatives (Kisel) the balinusra area begins with the hcm department recapitulating employee attendance lists. Then the human capital management (HCM) department recaps the results of employee performance evaluations through the KPI (Key Performance Indicator) program received. Cellular Telecommunication Cooperative (Kisel) Balinusra Region is an entity which has implemented a system in computerized payroll accounting to help the Balinusra Region Cellular Telecommunication Cooperative in processing data quickly, easily and can support work productivity. Adempiere is a program used by companies in the payroll process. The following is an analysis of the results of observations that will be grouped based on indicators from the accounting information system components:

1)People

Salaries received by employees of the selular telecommunication cooperative (Kisel) in balinusra region are managed by the Human Capital Management (HCM) department and the finance $\&$ accounting department. From the data that has been managed and authorized by the general manger, then the finance \& accounting department directly distributes salaries to each savings account Employee. The finance \& accounting department submits the pay slip as proof of the salary details received by each employee each month. This is in accordance with the components of the accounting information system according to romney because the seluklar telecommunications cooperative (kisel) in balinusra region has a finance \& accounting department as people who can use and perform their functions.

2)Procedure and instructions

In the payroll process the procedure starts with recording time attendance, making a payroll, distributing salary costs, making proof of cash out and paying salaries. Record time is present using the fingerprint system to be recapitulated every month by the Human Capital Management (HCM) department. The payroll is made by the Human Capital Management (HCM) department then the finance \& accounting department distributes employee salaries to a savings account and creates proof of cash out and proof of salary payment. Procedures and instructions are in accordance according to the theory adapted to the Cellular Telecommunication Cooperative (Kisel) in Balinusra Region.

3)Data

The payroll process at the Balinusra Regional Cellular Telecommunications Cooperative (Kisel) is recorded on supporting documents on changes in salary, hours of attendance cards, hours of work cards, payroll, salary list recap, salary statement and proof of cash out. Employees receive pay slips as evidence and details of salary that have been distributed. The data component as information for managing salaries is sufficient in accordance with the needs of the Balinusra Regional Telecommunications Communication Cooperative (Kisel). There is a missing data component which is the salary envelope because the Telecommunications Cellular Cooperative (Kisel) of the Balinusra Region provides salary through transfers to the savings accounts of each employee.

4) Software

From the observations and interviews that have been carried out, the departments and divisions related to payroll have used software namely Microsoft Excel which helps in managing salaries, recording, storing and preparing reports.

5) Information technology infrastructure.

Balinusra Regional Cellular Telecommunications Cooperative (Kisel) has completed information technology infrastructure such as computers connected between the head office and branches as well as adequate peripheral devices. The existence of technological infrastructure such as computers connected online makes it easy for each part to access data and information in real time.

6) Internal control.

All the main elements of internal control have been carried out by the Cellular Telecommunication Cooperative (Kisel) in the Balinusra Region. The main elements of the internal control system are: Organizational Structure, Authority System and Procedures, Healthy Work Implementation, and Qualified Employees.

Payroll accounting information system on Cellular Telecommunication Cooperatives (Kisel) The Balinusra region has gone well. The objectives of the accounting information system have been fulfilled because every component of the accounting information system that is people, procedures and instructions, data, software and information technology infrastructure is complete. 


\section{CONCLUSIONS}

Based on the results of research and discussion of the payroll accounting information system at the Selular Telecommunication Cooperative (Kisel) in Balinusra Region, it can be concluded that the accounting information system in the payroll process has gone well because it is in accordance with the theory. The use of a computerized system greatly simplifies the task of each part related to payroll in collecting, storing, and processing data. Computers that are connected online are very useful for the information needs needed because they can access data and information in real-time.

In addition, the Cellular Telecommunication Cooperative (Kisel) in Balinusra Region has a Flowchart of payroll system that has been set in accordance with the respective responsibilities and authorities in each part of the department. The accounting information system that has been implemented well can be seen from the six components of the information system accounting in information providers for decision makers and implementation in the operational activities of the Balinusra Regional Cellular Telecommunications Cooperative. The six components are people, procedures, data, software, information technology infrastructure and internal control components.

\section{LIMITATIONS AND FUTURE RESEARCH}

Researchers cannot see directly the documents and financial statements that are confidential, researchers only get evidence supporting documents for the payroll system, the sample used only gets one company. for further research is expected to use a wider sample and add variables associated with accounting information systems.

\section{REFERENCES}

1. Hall, James. Accounting Information System. Seventh Edition. USA: Cengage Learning. 2011

2. Fontinelle. Introduction To Accounting Information Systems. 2011

3. Rom, A and Rohde, C. Management Accounting and Integrated Information System: a literature review. International Journal of Accounting Information System. Vol.8 No.1, pp: 40-68. 2007. https://doi.org/10.1016/j.accinf.2006.12.003

4. Hall, James. Financial reporting and manangement reporting systems. AIS by JA Hall 7th ed Cengage Learning, pp: 349-393. 2014.

5. Varajão, A. Trigo, and J. Barroso, Motivations and Trends for IT/IS Adoption: Insights from Portuguese Companies. International Journal of Enterprise Information Systems (IJEIS). Vol. 5, pp: 34-52. 2009. https://doi.org/10.4018/jeis.2009090203

6. Trigo, J. Varajão, J. Barroso, P. Soto-Acosta, F. J. Molina-Castillo, and N. Gonzalvez-Gallego. Enterprise Information Systems Adoption in Iberian Large Companies: Motivations and Trends in
Managing Adaptability, Intervention, and People in Enterprise Information Systems. 2011.

7. Rom, A and Rohde, C. Enterprise resource planning systems, strategic enterprise management systems and management accounting: a Danish study. Journal of Enterprise Information Management. Vol. 19, pp: 50-66. 2006 https://doi.org/10.1108/17410390610636878

8. Grabski, S. A. Leech, and P. J. Schmidt. A Review of ERP Research: A Future Agenda for Accounting Information Systems. Journal of Information Systems. Vol. 25, pp: 37-78. 2011.

9. Yeo Symey, Suresh Sankaranarayanan , Siti Nurafifah binti Sait. Application of Smart Technologies for Mobile Patient Appointment System. International Journal of Advanced Trends in Computer Science and Engineering, 2(4), 74 - 85. 2013

10.Farag, Shawki M. The accounting profession in Egypt: Its origin and development. The International Journal of Accounting. Vol. 44 No.4, pp: 403-414. 2009.

https://doi.org/10.1016/j.intacc.2009.09.001

11.Yeboah, E., K.O. Kwateng, and C. Oppong. Information Systems And Accounting Practices In Ghanaian Public Institutions. Accounting \& Taxation. Vol.6 No.1, pp: 121-132. 2014.

12.Liu, Q and M.A. Vasarhelyi.. Big Questions in AIS Research: Measurement, Information Processing, Data Analysis, and Reporting. Journal of Information Systems. Vol. 28 No.1, pp: 1-17. 2014

13.Baker, G . On a payroll. $N Z$ Bus. Vol. 28 No.1, pp: 32-37. 2014.

14.Anonymous. How limited is your technology? Corporate Adviser (Online Edition). p: 1. 2014.

15.Fister, G. Hey you get into my cloud. Workforce. Vol.93 No.8, pp: 44-48. 2014.

16.Sorbanes-Oxley Act. 2002. www.usgov.org

17.Anonymous. Technology and business new. Payroll Manager Rep. Vol.15 No.1. 2011.

18. McCure, D. New directions in payroll. Account Today. Vol. 28 No.6, pp: 34-36. 2014.

19.Thite, $\mathrm{M}$ and Sandhu, $\mathrm{K}$. Where is my pay? Critical success factors of a payroll system- a system lifecycle approach. Aust J Inf Syst. Vol.18 No.2, pp: 149-164. 2014.

https://doi.org/10.3127/ajis.v18i2.820

20.Torres, E.N. \& Kline, S.F. From Satisfaction to Delight: A Model for the Hotel Industry. International Journal of Contemporary Hospitality Management. Vol.18 No.4, pp: 290- 301. 2006.

21.Maroudas, L., Kyriakidou, O. \& Vacharis, A. Employees' Motivation in the Luxury Hotel Industry: The Perceived Effectiveness of 
Ni Nyoman Sudiyani et al., International Journal of Advanced Trends in Computer Science and Engineering, 8(1.5), 2019, 199 - 205

Human-resource Practices. Managing leisure. Vol.13

No.3-4, pp: 258-27. 2008.

https://doi.org/10.1080/13606710802200969

22.Mahar Faizullah. Role of Information Technology in

Transaction Processing. Information Technology Journal. Vol.2, pp: 128-34. 2003.

23. Cardoso, JKV. Service engineering for the internet of services. Enterprise information systems, pp: 15-27. 2015.

https://doi.org/10.1007/978-3-642-00670-8_2

24.Busman, RA. Transparency, financial accounting information, and corporate governence. Economic policy review. 2013

25.T. Hariguna, CW. Hung, \& H.T. Sukmana, "The antecedent of citizen intention use of e-government service, TELKOMNIKA (Telecommunication Computing Electronics and Control)", 17(1), 202-209, 2019.

http://doi.org/10.12928/TELKOMNIKA.v17i1.11588

26. R. C. Gustilo, J. R. A. Danting, L. P. M. De Vera, B. J. Ramos, and L. Villanueva, "Design of Multi-Purpose Heavy-duty Scanning Robot with Spray Mechanism," Int. J. Adv. Trends Comput. Sci. Eng., vol. 8, no. 3, pp. 561-566, 2019.

https://doi.org/10.30534/ijatcse/2019/35832019 